\title{
Oxidovanadium complexes with tridentate aroylhydrazone as catalyst precursors for solvent-free microwave-assisted oxidation of alcohols
}

\author{
Manas Sutradhar ${ }^{\mathrm{a}}$, Luísa M.D.R.S. Martinss ${ }^{\mathrm{a}, \mathrm{b}}$, M. Fátima C. Guedes da Silva ${ }^{\mathrm{a}}$, \\ Armando J.L. Pombeiro ${ }^{\mathrm{a}, *}$ \\ a Centro de Química Estrutural, Instituto Superior Técnico, Universidade de Lisboa, Av. Rovisco Pais, 1049-001 Lisboa, Portugal \\ b Chemical Engineering Department, ISEL, R. Conselheiro Emídio Navarro, 1959-007 Lisboa, Portugal
}

\section{A R T I C L E I N F O}

\section{Article history:}

Received 26 August 2014

Received in revised form

16 December 2014

Accepted 5 January 2015

Available online 13 January 2015

\section{Keywords:}

Oxidovanadium complexes

Aroylhydrazone

$\mathrm{X}$-ray structure

Microwave-assisted oxidation

\begin{abstract}
A B S T R A C T
Aroylhydrazone oxidovanadium compounds, viz. the oxidoethoxidovanadium(V) $[\mathrm{VO}(\mathrm{OEt}) \mathrm{L}](\mathbf{1})\left(\mathrm{H}_{2} \mathrm{~L}\right.$ = salicylaldehyde-2-hydroxybenzoylhydrazone), the salt like dioxidovanadium(V) $\left(\mathrm{NH}_{3} \mathrm{CH}_{2} \mathrm{CH}_{2} \mathrm{OH}\right)^{+}$ $\left[\mathrm{VO}_{2} \mathrm{~L}\right]^{-}(\mathbf{2})$, the mixed-ligand oxidovanadium $(\mathrm{V})[\mathrm{VO}(\mathrm{hq}) \mathrm{L}](\mathrm{Hhq}=8$-hydroxyquinoline $)(3)$ and the vanadium(IV) [VO(phen)L] (phen = 1,10-phenanthroline) (4) complexes ( 3 and $\mathbf{4}$ obtained by the first time), have been tested as catalysts for solvent-free microwave-assisted oxidation of aromatic and alicyclic secondary alcohols with tert-butylhydroperoxide. A facile, efficient and selective solvent-free synthesis of ketones was achieved with yields up to $99 \%$ (TON $=497, \mathrm{TOF}=993 \mathrm{~h}^{-1}$ for 3 ) and $58 \%(\mathrm{TON}=291$, $\mathrm{TOF}=581 \mathrm{~h}^{-1}$ for $\mathbf{2}$ ) for acetophenone and cyclohexanone, respectively, after $30 \mathrm{~min}$ under low power $(25 \mathrm{~W})$ microwave irradiation.
\end{abstract}

() 2015 Elsevier B.V. All rights reserved.

\section{Introduction}

Functionalized oxygenated products, namely ketones, are on the basis of important industrial synthetic strategies, as solvents, polymer precursors and substrates for the syntheses, e.g., of pharmaceuticals, agrochemicals and fragrances [1-4]. Within the vast ketone synthetic methods, recent efforts focus on energy- and atom-efficiency, elimination of the use of hazardous substances, and reduction of time and of the generation of toxic (e.g. organic solvents) and heavy-metal wastes [5-9]. Hence, aerobic [10-13] and peroxidative [14-16] selective oxidations of secondary alcohols are regarded as simple and very useful synthetic methods for the preparation of ketones, this conversion being of a pivotal significance in organic synthesis. Moreover, it is known that microwave (MW) irradiation can provide a much more efficient synthetic method than conventional heating, allowing to achieve similar (or higher) yields in a shorter time and/or to improve the selectivity [17-27].

There is also a strong interest in the design of oxidation catalysts based on earth-abundant metals, such as vanadium. Oxidovanadium complexes are good candidates as catalysts for oxidation reactions, e.g., of alkanes [28-34]. They also catalyze [35-39] (or co-catalyze) the aerobic oxidation of secondary alcohols with good

\footnotetext{
* Corresponding author. Tel.: +351 218419237; fax: +351 218464455

E-mail address: pombeiro@tecnico.ulisboa.pt (A.J.L. Pombeiro).
}

yields and high selectivities, either in liquid or supported systems. The use of polyoxidovanadates has also been reported for the efficient oxidation of benzylic alcohols to the corresponding carbonyl compounds with $p$-toluenesulfonic acid [40]. However, the vanadium catalyzed peroxidative oxidation of secondary alcohols is comparatively scarce [35-39,41-43]. Some efficient systems concern the use of tert-butylhydroperoxide (TBHP) in the presence of silica [41] or graphene [42] supported oxidovanadium Schiff bases, or of hydrogen peroxide in a homogeneous mixture composed of vanadate, acid and TEMPO functionalized ionic liquids [43]. To our knowledge there is no report for solvent-free MW-assisted oxidation of secondary alcohols catalyzed by vanadium complexes.

On the other hand, aroylhydrazones are known to form stable complexes with vanadium in +4 or +5 oxidation states [44-48]. Therefore, the main objective of the present study was to establish the viability of oxidovanadium complexes based on an aroylhydrazone ligand as possible catalyst precursors for alcohols oxidation under the above conditions (in the absence of added solvent and under MW irradiation). We thus report herein the preparation and characterization of the novel complexes [VO(hq)L] $\left(\mathrm{H}_{2} \mathrm{~L}=\right.$ salicylaldehyde-2-hydroxybenzoylhydrazone, Hhq =8-hydroxyquinoline) (3) and [VO(phen)L] (phen $=1,10$-phenanthroline) (4), and their use, as well as of the known related compounds [VO $(\mathrm{OEt}) \mathrm{L}](\mathbf{1})$ and $\left(\mathrm{NH}_{3} \mathrm{CH}_{2} \mathrm{CH}_{2} \mathrm{OH}\right)^{+}\left[\mathrm{VO}_{2} \mathrm{~L}\right]^{-}(\mathbf{2})$, as catalysts for the peroxidative oxidation of 1-phenylethanol and cyclohexanol under green and mild reaction conditions. Those model reactions 
Table 1

Spectroscopic characterization data for $\mathbf{3}$ and $\mathbf{4}$

\begin{tabular}{|c|c|c|c|c|c|}
\hline \multirow[t]{2}{*}{ Catalyst precursor } & \multirow[t]{2}{*}{$\operatorname{IR}\left(\mathrm{KBr}, \mathrm{cm}^{-1}\right)$} & ${ }^{1} \mathrm{H}$ NMR & \multirow[t]{2}{*}{${ }^{51} \mathrm{~V}$ NMR } & \multirow[t]{2}{*}{$\begin{array}{l}\text { ESI-MS(+) } \\
m / z\end{array}$} & \multirow[t]{2}{*}{$\begin{array}{l}\lambda_{\max } \\
\left(\mathrm{CH}_{3} \mathrm{CN}, \mathrm{nm}(\varepsilon,\right. \\
\left.\left.\mathrm{L} \mathrm{M}^{-1} \mathrm{~cm}^{-1}\right)\right)\end{array}$} \\
\hline & & $\left(\right.$ DMSO- $\left.d_{6}, \delta\right)$ & & & \\
\hline 3 & $\begin{array}{l}1599 v(\mathrm{C}=\mathrm{N}), 1257 \\
v(\mathrm{C}-\mathrm{O}) \text { enolic, } 1103 \\
\nu(\mathrm{N}-\mathrm{N}), 955 v(\mathrm{~V}=\mathrm{O})\end{array}$ & $\begin{array}{l}11.12(\mathrm{~s}, 1 \mathrm{H}, \mathrm{OH}), 8.59 \\
(\mathrm{~s}, 1 \mathrm{H},-\mathrm{CH}=\mathrm{N}) \\
8.26-6.78(\mathrm{~m}, 14 \mathrm{H}, \\
\left.\mathrm{C}_{6} \mathrm{H}_{4} \text { and } \mathrm{C}_{9} \mathrm{H}_{6} \mathrm{NO}\right)\end{array}$ & -478 & $\begin{array}{l}466[3+\mathrm{H}]^{+} \\
(100 \%)\end{array}$ & $\begin{array}{l}552(4480), 331 \\
(13,440), 273(21,280), \\
240(34,720) .\end{array}$ \\
\hline 4 & $\begin{array}{l}1603 \nu(\mathrm{C}=\mathrm{N}), 1252 \\
\nu(\mathrm{C}-\mathrm{O}) \text { enolic, } 1056 \\
\nu(\mathrm{N}-\mathrm{N}), 961 \nu(\mathrm{V}=\mathrm{O})\end{array}$ & - & - & $\begin{array}{l}502[4+\mathrm{H}]^{+} \\
(100 \%)\end{array}$ & $\begin{array}{l}701(41.2), 412 \\
(15,600), 351(18,540) \\
269(45,320) .\end{array}$ \\
\hline
\end{tabular}

are justified by their importance in organic synthesis and chemical industry $[3,49]$.

\section{Experimental}

\subsection{Preparation of catalyst precursors}

The Schiff base pro-ligand salicylaldehyde-2hydroxybenzoylhydrazone $\left(\mathrm{H}_{2} \mathrm{~L}\right)$ was prepared by a reported method [50,51] from condensation of 2-hydroxybenzoylhydrazide with salicylaldehyde. The catalyst precursors [VO(OEt)L] (1) and $\left(\mathrm{NH}_{3} \mathrm{CH}_{2} \mathrm{CH}_{2} \mathrm{OH}\right)^{+}\left[\mathrm{VO}_{2} \mathrm{~L}\right]^{-}$(2) were synthesized according to literature methods [50-52]. The syntheses of the other two catalyst precursors, the oxidovanadium $(\mathrm{V})$ complex $[\mathrm{VO}(\mathrm{hq}) \mathrm{L}](\mathbf{3})$ and the oxidovanadium(IV) complex [VO(phen)L] (4), are described below.

Oxidovanadium(V) complex [VO $(h q) L](3)$ - To a $30 \mathrm{~mL}$ acetonitrile suspension of $\mathrm{H}_{2} \mathrm{~L}(0.256 \mathrm{~g}, 1.00 \mathrm{mmol}), 0.265 \mathrm{~g}(1.00 \mathrm{mmol})$ of $\left[\mathrm{VO}(\mathrm{acac})_{2}\right]$ was added and the reaction mixture was refluxed for $1 \mathrm{~h}$ in an oil bath, in open air. To this mixture $0.145 \mathrm{~g}(1.00 \mathrm{mmol})$ of 8-hydroxyquinoline (Hhq) was added and the reflux was continued for another hour. The resultant dark violet solution was filtered and the filtrate was kept in air. After ca. 2 d, X-ray quality dark violet single crystals were isolated, washed 3 times with cold acetonitrile and dried in open air. Yield 76\% ( $0.353 \mathrm{~g}$, based on vanadium). Anal. Calcd for $\mathrm{C}_{23} \mathrm{H}_{16} \mathrm{~N}_{3} \mathrm{O}_{5} \mathrm{~V}$ : C, 59.37; $\mathrm{H}, 3.47 ; \mathrm{N}, 9.03$. Found: 59.28; $\mathrm{H}$, 3.39; N, 8.91. Spectroscopic and ESI-MS data are given in Table 1.

Oxidovanadium(IV) complex [VO(phen)L] (4) - This complex was isolated as orange red crystals using the procedure adopted in the preparation of 3 but with 1,10-phenanthroline (phen) instead of 8hydroxyquinoline (Hhq). Yield $72 \%$ ( $0.360 \mathrm{~g}$, based on vanadium). Anal. Calcd for $\mathrm{C}_{26} \mathrm{H}_{18} \mathrm{~N}_{4} \mathrm{O}_{4} \mathrm{~V}$ : C, 62.28; $\mathrm{H}, 3.62 ; \mathrm{N}, 11.17$. Found: 61.96; H, 3.56; N, 11.09. Spectroscopic and ESI-MS data are given in Table 1.

\subsection{Characterization of catalyst precursors}

\subsubsection{General materials and procedures}

All synthetic work was performed in air. The reagents and solvents were obtained from commercial sources and used as received, i.e., without further purification or drying. Complexes $\mathbf{1}$ and $\mathbf{2}$ were synthesized according to the reported procedure [50-52]. $\left[\mathrm{VO}(\mathrm{acac})_{2}\right]$ was used as the metal source for the synthesis of complexes 3 and 4. C, H, and N elemental analyses were carried out by the Microanalytical Service of the Instituto Superior Técnico. Infrared spectra $\left(4000-400 \mathrm{~cm}^{-1}\right)$ were recorded on a BRUKER VERTEX 70 or Jasco FT/IR-430 instrument in $\mathrm{KBr}$ pellets, wavenumbers are in $\mathrm{cm}^{-1}$. Mass spectra were run in a Varian 500-MS LC Ion Trap Mass Spectrometer equipped with an electrospray (ESI) ion source. For electrospray ionization, the drying gas and flow rate were optimized according to the particular sample with 35 p.s.i. nebulizer pressure. Scanning was performed from $\mathrm{m} / \mathrm{z} 100$ to 1200 in acetonitrile solution. The compounds were observed in the positive mode (capillary voltage $=80-105 \mathrm{~V}$ ). The ${ }^{1} \mathrm{H}$ spectra were recorded at room temperature on a Bruker Avance II+300 (UltraShield ${ }^{\mathrm{TM}}$ Magnet) spectrometer operating at $300.130 \mathrm{MHz}$ for proton. The chemical shifts are reported in ppm using tetramethylsilane as the internal reference. ${ }^{51} \mathrm{~V}$ NMR spectra were recorded on a Bruker 400 UltraShield spectrometer at ambient temperature (297 K) in DMSO$d_{6}$. The vanadium chemical shifts are quoted relative to external $\left[\mathrm{VOCl}_{3}\right]$. The UV-Vis absorption spectra of acetonitrile solutions of $\mathbf{3}\left(1.12 \times 10^{-5} \mathrm{M}\right)$ and $\mathbf{4}\left(1.03 \times 10^{-5} \mathrm{M}\right)$ in $1.00 \mathrm{~cm}$ quartz cells were recorded at room temperature on a Lambda $35 \mathrm{UV}-\mathrm{Vis}$ spectrophotometer (Perkin-Elmer) by scanning the $200-1000 \mathrm{~nm}$ region at a rate of $240 \mathrm{~nm} \mathrm{~min}^{-1}$.

\subsubsection{X-ray measurements}

X-ray single crystals of complexes $\mathbf{3}$ and $\mathbf{4}$ were immersed in cryo-oil, mounted in Nylon loops and measured at a temperature of 150 (3) or $296 \mathrm{~K}$ (4). Crystals of 4 were of bad quality and very weakly diffracting (see Supplementary Information file). Intensity data were collected using a Bruker AXS-KAPPA APEX II or Bruker APEX-II PHOTON 100 with graphite monochromated Mo-K $\alpha$ ( $\lambda$ 0.71073) radiation. Data were collected using omega scans of $0.5^{\circ}$ per frame and full sphere of data were obtained. Cell parameters were retrieved using Bruker SMART [53] software and refined using Bruker SAINT [53] on all the observed reflections. Absorption corrections were applied using SADABS [53]. Structures were solved by direct methods by using the SHELXS97 package [54] and refined with SHELXL-97 [54]. Calculations were performed using the WinGX System-Version 1.80.03 [55]. The hydrogen atoms were inserted in calculated positions. Least square refinements with anisotropic thermal motion parameters for all the non-hydrogen atoms and isotropic for the remaining atoms were employed. There were disordered solvents present in the structures of both compounds. Since no obvious major site occupations were found for those molecules, it was not possible to model them. PLATON/SQUEEZE [56] was used to correct the data and potential volume of 119 (3) and 221 (4) $\AA^{3}$ were found with, respectively, 30 and 66 electrons per unit cells worth of scattering. These were removed from the model, but not included in the empirical formula. Crystallographic data are summarized in Table 2 and selected bond distances and angles are presented in Table 3. CCDC 1005764 (3) and 1005765 (4) contain the supplementary crystallographic data for this paper. These data can be obtained free of charge from The Cambridge Crystallographic Data Centre via www.ccdc.cam.ac.uk/data_request/cif.

\subsection{Catalytic tests}

\subsubsection{Solvent-free microwave-assisted oxidation of secondary alcohols}

The catalytic tests under MW irradiation were performed in a focused microwave Anton Paar Monowave 300 discover reactor $(25 \mathrm{~W})$, using a $10 \mathrm{~mL}$ capacity reaction tube with a $13 \mathrm{~mm}$ internal 
Table 2

Crystal data and structure refinement details for complexes $\mathbf{3}$ and $\mathbf{4}$.

\begin{tabular}{|c|c|c|}
\hline & 3 & 4 \\
\hline Empirical formula & $\mathrm{C}_{23} \mathrm{H}_{16} \mathrm{~N}_{3} \mathrm{O}_{5} \mathrm{~V}$ & $\mathrm{C}_{26} \mathrm{H}_{18} \mathrm{~N}_{4} \mathrm{O}_{4} \mathrm{~V}$ \\
\hline Formula Weight & 465.33 & 501.38 \\
\hline Crystal system & Triclinic & Triclinic \\
\hline Space group & $\mathrm{P}-1$ & P-1 \\
\hline$a / \AA$ & $8.1264(10)$ & $12.3188(12)$ \\
\hline$b / \AA$ & $11.8080(15)$ & $12.5684(12)$ \\
\hline$c / \AA$ & $12.5868(15)$ & $16.4642(15)$ \\
\hline$\alpha /^{\circ}$ & $112.746(5)$ & $85.024(5)$ \\
\hline$\beta 1^{\circ}$ & $101.275(8)$ & $71.596(4)$ \\
\hline$\gamma /{ }^{\circ}$ & $96.266(5)^{\circ}$ & $88.915(4)$ \\
\hline$V\left(\AA^{3}\right)$ & $1069.3(2)$ & $2409.5(4)$ \\
\hline$Z$ & 2 & 4 \\
\hline$D_{\text {calc }}\left(\mathrm{g} \mathrm{cm}^{-3}\right)$ & 1.445 & 1.382 \\
\hline$\mu(\operatorname{Mo~K} \alpha)\left(\mathrm{mm}^{-1}\right)$ & 0.504 & 0.451 \\
\hline Rfls. collected/unique/observed & $19,619 / 3892 / 2841$ & $28,101 / 8122 / 2228$ \\
\hline$R_{\text {int }}$ & 0.0673 & 0.2054 \\
\hline Final $R 1^{\mathrm{a}}, w R 2^{\mathrm{b}}(I \geq 2 \sigma)$ & $0.0679,0.1834$ & $0.1299,0.3363$ \\
\hline Goodness-of-fit on $F^{2}$ & 1.037 & 0.927 \\
\hline
\end{tabular}

Table 3

Selected bond distances $(\AA)$ and angles $\left(^{\circ}\right)$ in complex 3.

\begin{tabular}{lr}
\hline $\mathrm{N} 1-\mathrm{V} 1$ & $2.090(3)$ \\
$\mathrm{N} 3-\mathrm{V} 1$ & $2.385(3)$ \\
$\mathrm{O} 1-\mathrm{V} 1$ & $1.852(3)$ \\
$\mathrm{O} 2-\mathrm{V} 1$ & $1.948(3)$ \\
$\mathrm{O} 4-\mathrm{V} 1$ & $1.840(3)$ \\
$\mathrm{O} 10-\mathrm{V} 1$ & $1.580(3)$ \\
$\mathrm{O} 10-\mathrm{V} 1-\mathrm{O} 4$ & $98.68(14)$ \\
$\mathrm{O} 10-\mathrm{V} 1-\mathrm{O} 1$ & $100.17(15)$ \\
$\mathrm{O} 4-\mathrm{V} 1-\mathrm{O} 1$ & $96.55(12)$ \\
$\mathrm{O} 10-\mathrm{V} 1-\mathrm{O} 2$ & $95.99(14)$ \\
$\mathrm{O} 4-\mathrm{V} 1-\mathrm{O} 2$ & $98.74(12)$ \\
$\mathrm{O} 1-\mathrm{V} 1-\mathrm{O} 2$ & $155.76(13)$ \\
$\mathrm{O} 10-\mathrm{V} 1-\mathrm{N} 1$ & $102.94(14)$ \\
$\mathrm{O} 4-\mathrm{V} 1-\mathrm{N} 1$ & $158.05(13)$ \\
$\mathrm{O} 1-\mathrm{V} 1-\mathrm{N} 1$ & $83.44(12)$ \\
$\mathrm{O} 2-\mathrm{V} 1-\mathrm{N} 1$ & $75.38(12)$ \\
$\mathrm{O} 10-\mathrm{V} 1-\mathrm{N} 3$ & $171.66(14)$ \\
$\mathrm{O} 4-\mathrm{V} 1-\mathrm{N} 3$ & $75.44(11)$ \\
$\mathrm{O} 1-\mathrm{V} 1-\mathrm{N} 3$ & $86.51(13)$ \\
O2-V1-N3 & $79.30(12)$ \\
$\mathrm{N} 1-\mathrm{V} 1-\mathrm{N} 3$ & $82.65(12)$ \\
\hline
\end{tabular}

diameter, fitted with a rotational system and an IR temperature detector. Gas chromatographic (GC) measurements were carried out using a FISONS Instruments GC 8000 series gas chromatograph with a DB-624 (J\&W) capillary column (FID detector) and the JascoBorwin v.1.50 software. The temperature of injection was $240^{\circ} \mathrm{C}$. The initial temperature was maintained at $120^{\circ} \mathrm{C}$ for $1 \mathrm{~min}$, then raised $10^{\circ} \mathrm{C} / \mathrm{min}$ to $200^{\circ} \mathrm{C}$ and held at this temperature for $1 \mathrm{~min}$. Helium was used as the carrier gas. GC-MS analyses were performed using a Perkin-Elmer Clarus $600 \mathrm{C}$ instrument (He as the carrier gas). The ionization voltage was $70 \mathrm{eV}$. Gas chromatography was conducted in the temperature-programming mode, using a SGE BPX 5 column $(30 \mathrm{~m} \times 0.25 \mathrm{~mm} \times 0.25 \mu \mathrm{m})$. Reaction products were identified by comparison of their retention times with known reference compounds, and by comparing their mass spectra to fragmentation patterns obtained from the NIST spectral library stored in the computer software of the mass spectrometer.

\subsubsection{Typical procedures for the catalytic oxidation of alcohols and product analysis}

Oxidation reactions of the alcohols were carried out in sealed cylindrical Pyrex tubes under focused MW irradiation as follows: the alcohol substrate $(5 \mathrm{mmol})$, catalyst precursor 1-4
(1-100 $\mu \mathrm{mol}, 0.02-2 \mathrm{~mol} \%$ vs. substrate) and a $70 \%$ aqueous solution of $\mathrm{Bu}^{t} \mathrm{OOH}$ or $\mathrm{H}_{2} \mathrm{O}_{2}(10 \mathrm{mmol})$ were introduced in the tube. This was then placed in the microwave reactor and the system was stirred and irradiated $(25 \mathrm{~W})$ for $0.25-1 \mathrm{~h}$ at $80^{\circ} \mathrm{C}$. After the reaction, the mixture was allowed to cool down to room temperature. $300 \mu \mathrm{L}$ of benzaldehyde (internal standard) and $5 \mathrm{~mL}$ of NCMe (to extract the substrate and the organic products from the reaction mixture) were added. The obtained mixture was stirred during $10 \mathrm{~min}$ and then a sample $(1 \mu \mathrm{L})$ was taken from the organic phase and analyzed by GC using the internal standard method. Blank tests indicate that only traces $(<0.7 \%)$ of acetophenone (or cyclohexanone) are generated in a V-free system.

\section{Results and discussion}

\subsection{Synthesis}

To examine the possible catalytic activity of oxidovanadium complexes with an aroylhydrazone ligand towards solvent-free MW-assisted oxidation of secondary alcohols under mild reaction conditions, we have used the vanadium complexes (1-4). Two of the complexes ( $\mathbf{1}$ and $\mathbf{2}$ ) were already known and were synthesized by a reported method [50-62], whereas the other two (3 and 4) were newly synthesized and are now reported (Scheme 1).

Complexes [VO(hq)L] (3) and [VO(phen)L] (4) are prepared by reaction of $\left[\mathrm{VO}(\mathrm{acac})_{2}\right]\left(\mathrm{acac}^{-}=\right.$acetyleacetonate $)$ in refluxing $\mathrm{CH}_{3} \mathrm{CN}$ with the Schiff base salicylaldehyde2-hydroxybenzoylhydrazone $\left(\mathrm{H}_{2} \mathrm{~L}\right)$, in the presence of 8-hydroxyquinoline (Hhq) or 1,10-phenanthroline (phen), respectively. They were isolated as dark violet (3) or orange red (4) crystalline solids, and characterized by IR, NMR (in the case of $\mathbf{3}$ ) and UV/Vis spectroscopies, elemental analysis, ESI-MS and single crystal X-ray diffraction (see below). [VO(hq)L] (3) and [VO(phen)L] (4) are hexacoordinate mixed-ligand oxidovanadium $(\mathrm{V})$ and oxidovanadium(IV) complexes, respectively, whereas the known [VO(OEt)L] (1) and $\left(\mathrm{NH}_{3} \mathrm{CH}_{2} \mathrm{CH}_{2} \mathrm{OH}\right)^{+}\left[\mathrm{VO}_{2} \mathrm{~L}\right]^{-}$(2) [59-61] are pentacoordinate oxidoethoxidovanadium $(\mathrm{V})$ compounds, where the sixth coordination position is available for further coordination.

It is well known that $\left[\mathrm{VO}(\mathrm{acac})_{2}\right.$ ] undergoes aerial oxidation in solution (preferably in alcohol medium) in the presence of hydrazone Schiff bases $[48,57,58]$. Sometimes, the presence of a neutral bidentate $\mathrm{N}, \mathrm{N}$ donor auxiliary ligand in $\mathrm{CH}_{3} \mathrm{CN}$ helps to stabilize the oxidovanadium(IV) centre, which can be isolated as a stable solid product $[59,60]$. Herein, we used two different bidentate auxiliary ligands to stabilize oxidovanadium centres in $\mathbf{3}$ and $\mathbf{4}$ : the mono negative 8-hydroxyquinolinate $\left(\mathrm{hq}^{-}\right)$and the neutral 1,10-phenanthroline (phen) which stabilize the vanadium(V) and the vanadium(IV) centre, respectively, with the tridentate hydrazone Schiff base $[48,59,60]$. The four complexes of this study (1-4) present different coordination environments and have been used for a comparative study of their catalytic activities towards solventfree MW-assisted oxidation of secondary alcohols.

\subsection{Spectroscopic characterization of the complexes}

The IR spectra of complexes 3 and $\mathbf{4}$ (Table 1) contain all the characteristic bands of the coordinated tridentate anionic ligand $\mathrm{L}^{2-}$ in the enol form, viz., 1599, 1257 and $1103 \mathrm{~cm}^{-1}$ for 3 and 1603, 1252 and $1056 \mathrm{~cm}^{-1}$ for 4 . In addition, the $v(\mathrm{~V}=0)$ bands are observed at 955 and $961 \mathrm{~cm}^{-1}$ for 3 and 4, respectively.

The ${ }^{1} \mathrm{H}$ NMR spectrum of 3 in DMSO- $d_{6}$ (Table 1 ) shows the characteristic resonance of the ligand [50,51]: the proton of the azomethine nitrogen at $8.59 \mathrm{ppm}$, the aromatic protons as multiplets in the range of $8.26-6.78 \mathrm{ppm}$, and the phenolic $\mathrm{OH}$ proton at $11.2 \mathrm{ppm}$. 


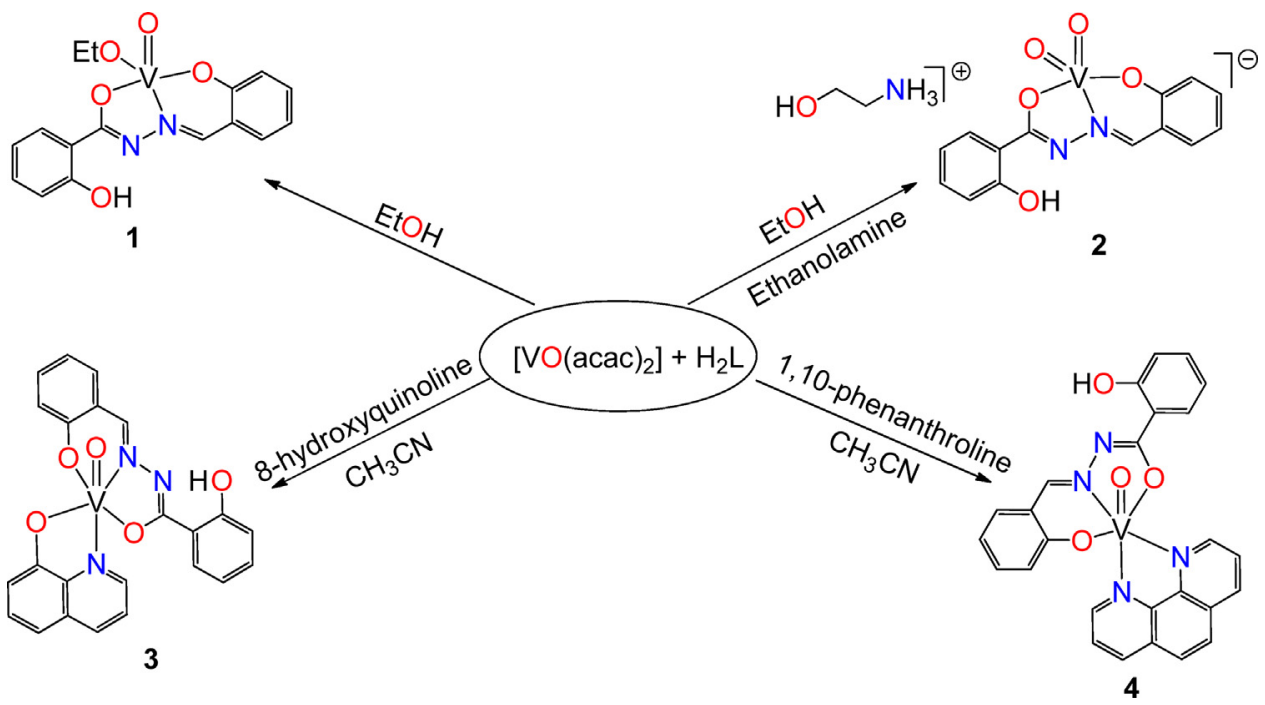

Scheme 1. Synthesis of vanadium complexes.

Complex 3 was also identified by the ${ }^{51} \mathrm{~V}$ NMR spectroscopy (Table 1). The spectrum shows characteristic peak at $-478 \mathrm{ppm}$ corresponds to oxidiovanadium(V) centre [48].

The electronic spectral data of the oxidovanadium complexes 3 and $\mathbf{4}$ are given in Table 1 . The electronic spectrum of the oxidovanadium $(V)$ complex $\mathbf{3}$ in acetonitrile solution displays a strong absorption at $552 \mathrm{~nm}$ assigned to the $\mathrm{PhO}^{-} \rightarrow \mathrm{V}\left(\mathrm{d}_{\pi}\right)$ LMCT transition and three other intense absorption band in the $331-240 \mathrm{~nm}$ region allocated to intraligand $\left(\pi \rightarrow \pi^{*}\right)$ transitions [59]. The oxidovanadium(IV) complex 4 exhibits a low intensity band at $701 \mathrm{~nm}$ due to ligand field $d_{x z}, d_{y z} \rightarrow d_{x y}$ transitions of the $\mathrm{VO}^{2+}$ centre [60]. The strong band observed at $412 \mathrm{~nm}$ is due to the $\mathrm{O}_{\text {enolate }} \rightarrow \mathrm{V}\left(\mathrm{d}_{\pi}\right)$ LMCT transition. Bands centred at 350 and $269 \mathrm{~nm}$ are assigned to intraligand transitions [60].

The ESI-MS spectra of $\mathbf{3}$ and $\mathbf{4}$ in acetonitrile solution (Table 1 ) display the parent peaks at $m / z=466[3+\mathrm{H}]^{+}(100 \%)$ and at $m / z=502$ $[4+\mathrm{H}]^{+}(100 \%)$ respectively, which also support the formulations.

\subsection{X-ray structural characterization}

The molecular structures of complexes $\mathbf{3}$ and $\mathbf{4}$ are depicted in Figs. 1 and 2, respectively, whereas crystal data are presented in Table 2 and selected bond distances and angles for $\mathbf{3}$ are given in Table 3. A discussion of the low quality structure of $\mathbf{4}$ is given in the Supplementary Information file whereas Table $\mathrm{S} 1$ shows distances and angles for this compound. The dianionic Schiff base ligand $\left(\mathrm{L}^{2-}\right)$ in 3 coordinates to vanadium(V) in the enol form (Fig. 1). The vanadium ion exhibits a distorted octahedral $\mathrm{O}_{4} \mathrm{~N}_{2}$ coordination (quadratic elongation of 1.048 and angle variance of $104.79^{\circ}$ ${ }^{2}$ ) in which the basal plane is made of the phenolic (O1), the enolic (O2) oxygen and the imine (N1) nitrogen atoms from the $\mathrm{L}^{2-}$ ligand together with a phenolic (O4) oxygen of the auxiliary quinolate ligand. The apical positions are occupied by the oxido (O10) and the pyridine nitrogen (N3) atom of the quinolate. The $\mathrm{L}^{2-}$ ligand binds the vanadium ion generating six-[V1-O1-C1-C6-C7-N1] and five-membered [V1-O2-C8-N2-N1] chelate rings.

The $\mathrm{L}^{2-}$ ligand in $\mathbf{3}$ deviates slightly from planarity. Indeed, relative to the least-square plane formed by the coordinating atoms $\mathrm{N} 1, \mathrm{O} 1$ and $\mathrm{O} 2$ (plane $A$ ), the least-square planes of the phenolate rings $\mathrm{C} 1>\mathrm{C} 6$ and $\mathrm{C} 9>\mathrm{C} 10$ make angles of 10.09 and $15.30^{\circ}$, respectively. The metal cation is situated $0.230 \AA$ away from plane $A$ and shifted towards the oxido atom; the least-square plane of the auxiliary ligand $\left(\mathrm{hq}^{-}\right)$makes an angle of $87.76^{\circ}$ with plane $A$. The V1-N3 distance of 2.385(3) $\AA$, with that nitrogen lying trans to the $\mathrm{O}_{\text {oxido }}$ atom, is much longer than the $\mathrm{V}-\mathrm{N}_{\text {Schiff }}$ bond length [V1-N1 2.090(3) A] what is due not only to the trans influence of the $\mathrm{O}_{\text {oxido }}$ atom but also to 5-membered ring constraints. The short $\mathrm{V}-\mathrm{O}_{\text {oxido }}$ distance [V1-O10 1.580 (3) $\AA$ ] is consistent with a vanadium-oxygen double bond $(\mathrm{V}=\mathrm{O})$ as it is commonly found in five- and six-coordinate vanadium (IV) and (V) complexes [48]; the two $\mathrm{V}-\mathrm{O}_{\text {phenolate }}$ lengths, $\mathrm{V} 1-\mathrm{O} 1$ from $\mathrm{L}^{2-}$ and the $\mathrm{V} 1-\mathrm{O} 4$ from hq $^{-}$[1.852(3) and 1.840(3) $\AA$, in this order], slightly differ and are shorter than the $\mathrm{V}-\mathrm{O}_{\text {enolate }}[\mathrm{V} 1-\mathrm{O} 2$ 1.948(3) $\AA$ ]. As previously found [48,59], the four vanadium-oxygen bond lengths in $\mathbf{3}$ follow the order: oxido $<$ phenolate $<$ enolate.

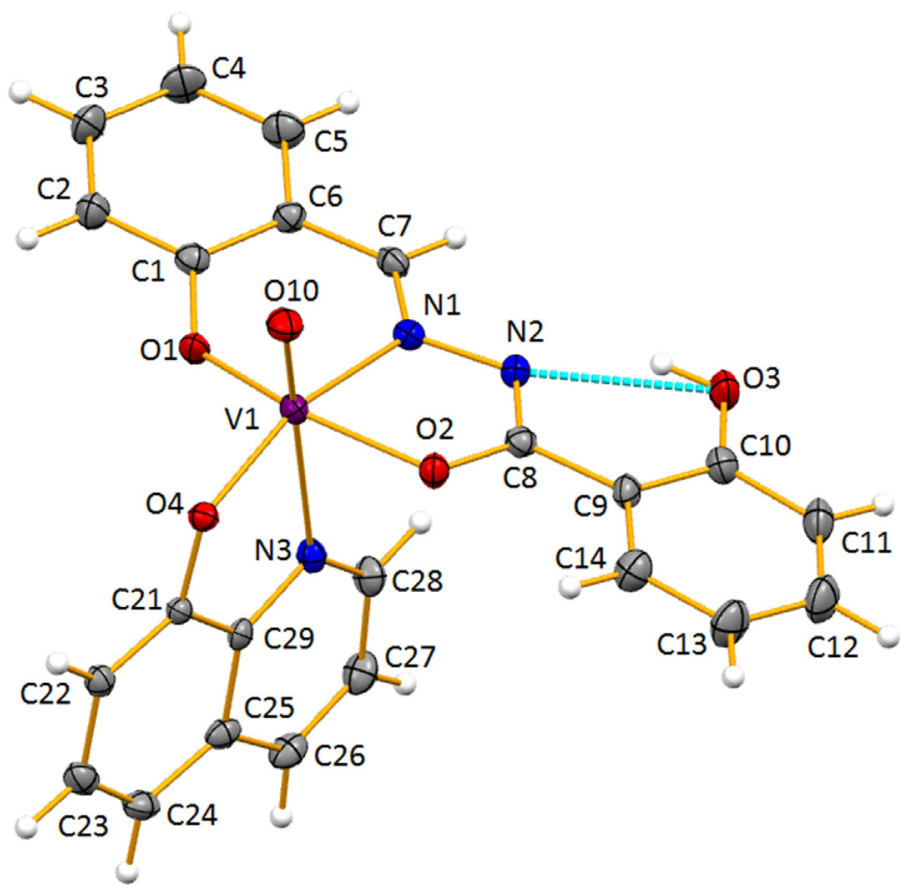

Fig. 1. Ellipsoid plot for complex $\mathbf{3}$ (drawn at the $30 \%$ probability level) with atom labelling scheme. 


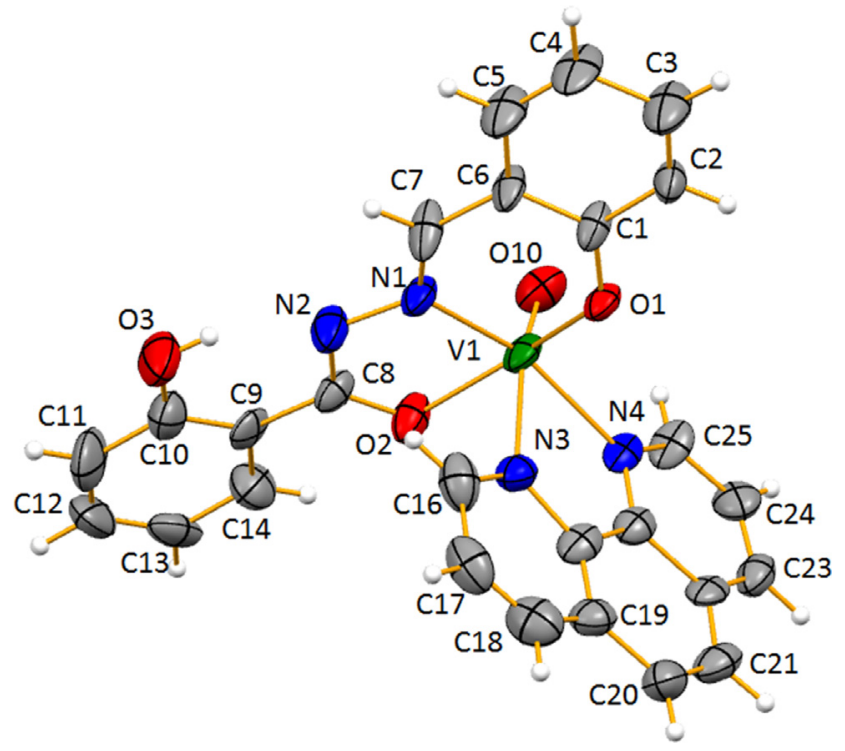

Fig. 2. Ellipsoid representation of one of the molecules of complex 4 (drawn at the $30 \%$ probability level) with atom labelling scheme.

\subsection{Oxidation of secondary alcohols}

Complexes 1-4 were tested as catalyst precursors for the homogeneous oxidation of aromatic and alicyclic secondary alcohols (1-phenylethanol and cyclohexanol were chosen as model substrates) to the respective ketones using aqueous tertbutylhydroperoxide $\left(\mathrm{Bu}^{t} \mathrm{OOH}, \mathrm{TBHP}\right)$ as oxidizing agent, under typical conditions of $80^{\circ} \mathrm{C}$, low power $(25 \mathrm{~W})$ microwave irradiation (MW), 30 min reaction time and in a solvent- and additive-free medium (Scheme 2).

Other $\mathrm{C}_{6}$ linear secondary alcohols (Table 5 ) were also tested as substrates, and the ketones are the only detected oxidation products. The effects of various reaction parameters, such as, the type and amount of oxidant, time, temperature, amount of catalyst precursor and presence of additives, were investigated and the results are summarized in Tables 4 and 5 and Figs. 3-6.

Under typical solvent- and additive-free conditions (Table 4) all catalyst precursors 1-4 exhibit a high activity [TON (TOF) values up to $1.8 \times 10^{3}\left(3.6 \times 10^{3} \mathrm{~h}^{-1}\right)(3)$ ], leading to yields (based on the alcohol) of acetophenone and cyclohexanone in the ranges of $77-94 \%$ and $30-38 \%$, respectively. A high selectivity towards the formation of ketones was displayed by these MW-assisted transformations, since no traces of by-products were detected by GC-MS analysis of the final reaction mixtures (only the unreacted alcohol was found, apart from the ketone).

Table 4

MW-assisted solvent-free oxidation of selected aromatic and alicyclic secondary alcohols using 1-4 as catalyst precursors. ${ }^{\mathrm{a}}$

\begin{tabular}{|c|c|c|c|c|c|}
\hline Entry & $\begin{array}{l}\text { Catalyst } \\
\text { precursor }\end{array}$ & Substrate & Yield $^{\mathrm{b}}(\%)$ & $\operatorname{TOF}\left(h^{-1}\right)^{c}$ & Selectivity (\%) ${ }^{\mathrm{d}}$ \\
\hline 1 & 1 & 1-Phenylethanol & 94.3 & 943 & 98 \\
\hline 2 & & Cyclohexanol & 36.1 & 361 & 90 \\
\hline 3 & 2 & 1-Phenylethanol & 77.1 & 771 & 94 \\
\hline 4 & & Cyclohexanol & 37.6 & 376 & 92 \\
\hline 5 & & & 92.6 & 926 & 97 \\
\hline $6^{\mathrm{e}}$ & & 1-Phenylethanol & 36.3 & $3.64 \times 10^{3}$ & 93 \\
\hline $7^{f}$ & 3 & & 90.9 & 91 & 86 \\
\hline 8 & & & 30.3 & 303 & 91 \\
\hline $9^{e}$ & & Cyclohexanol & 12.3 & $1.2 \times 10^{3}$ & 83 \\
\hline $10^{f}$ & & & 30.1 & 30 & 72 \\
\hline 11 & 4 & 1-Phenylethanol & 86.4 & 863 & 92 \\
\hline 12 & & Cyclohexanol & 35.4 & 354 & 87 \\
\hline
\end{tabular}

${ }^{\text {a }}$ Reaction conditions unless stated otherwise: $5 \mathrm{mmol}$ of substrate, $10 \mu \mathrm{mol}(0.2 \mathrm{~mol} \%$ vs. substrate $)$ of $\mathbf{1}-\mathbf{4}, 10 \mathrm{mmol}$ of $\mathrm{TBHP}\left(2 \mathrm{eq}\right.$., $70 \%$ in $\left.\mathrm{H}_{2} \mathrm{O}\right), 80{ }^{\circ} \mathrm{C}, 30 \mathrm{~min}$ of $\mathrm{MW}$ irradiation (25 W power).

b Moles of ketone product per 100 moles of alcohol.

c $\mathrm{TOF}$ = number of moles of product per mol of catalyst precursor (TON) per hour.

d Moles of ketone per mole of converted substrate.

e $1 \mu \mathrm{mol}(0.02 \mathrm{~mol} \%$ vs. substrate $)$ of $\mathbf{3}$.

f $100 \mu \mathrm{mol}$ ( $2 \mathrm{~mol} \%$ vs. substrate) of 3.

Table 5

MW-assisted solvent-free oxidation of selected linear secondary alcohols using 1-4 as catalyst precursors ${ }^{\mathrm{a}}$.

\begin{tabular}{|c|c|c|c|c|c|}
\hline Entry & Substrate & Catalyst precursor & Yield $^{\mathrm{b}}(\%)$ & $\operatorname{TOF}\left(h^{-1}\right)^{c}$ & Selectivity (\%) \\
\hline 1 & & 1 & 29.4 & 59 & 79 \\
\hline 7 & 2-Hexanol & 2 & 40.2 & 80 & 87 \\
\hline 8 & & 3 & 35.6 & 71 & 82 \\
\hline 9 & & 4 & 31.9 & 64 & 67 \\
\hline 11 & & 1 & 32.3 & 65 & 84 \\
\hline 13 & 3-Hexanol & 2 & 32.8 & 66 & 79 \\
\hline 19 & & 3 & 28.9 & 58 & 73 \\
\hline 20 & & 4 & 28.1 & 56 & 52 \\
\hline
\end{tabular}

a Reaction conditions unless stated otherwise: $5 \mathrm{mmol}$ of substrate, $10 \mu \mathrm{mol}(0.2 \mathrm{~mol} \%$ vs. substrate $)$ of $\mathbf{1 - 4}, 10 \mathrm{mmol}$ of $\mathrm{TBHP}\left(2 \mathrm{eq} ., 70 \%\right.$ in $\left.\mathrm{H}_{2} \mathrm{O}\right), 80{ }^{\circ} \mathrm{C}, 2 \mathrm{~h} 30 \mathrm{~min}$ of $\mathrm{MW}$ irradiation ( $25 \mathrm{~W}$ power).

b Moles of ketone product per 100 moles of alcohol.

c $\mathrm{TOF}=$ number of moles of product per mol of catalyst precursor (TON) per hour.

d Moles of ketone per mole of converted substrate. 


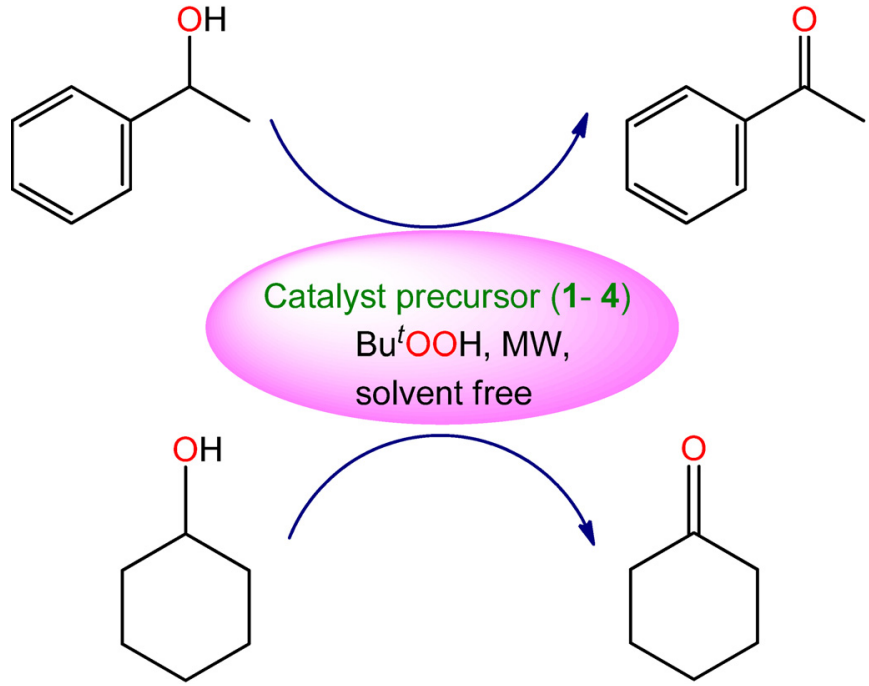

Scheme 2. Solvent-free homogeneous oxidation of 1-phenylethanol and cyclohexanol to acetophenone and cyclohexanone, respectively, by the 1-4/TBHP/MW system.

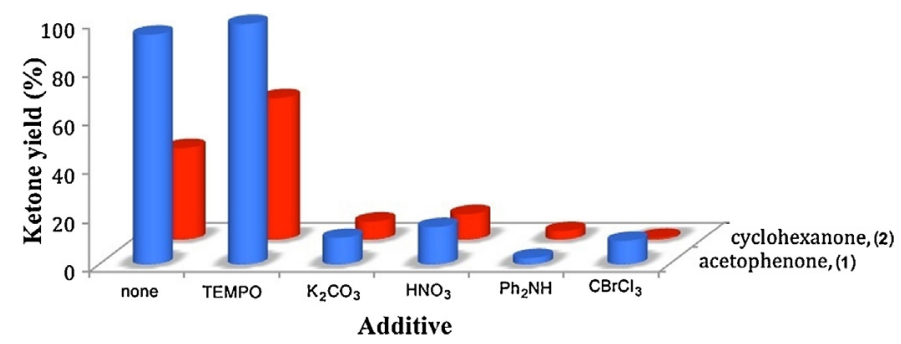

Fig. 3. Influence of different additives (TEMPO, $\mathrm{K}_{2} \mathrm{CO}_{3}, \mathrm{HNO}_{3}$, radical traps) on the yield of acetophenone $(\square$ ) or of cyclohexanone $(\square$ ) obtained from MW-assisted peroxidative oxidation of 1-phenylethanol in the presence of $\mathbf{1}$ or of cyclohexanol in the presence of $\mathbf{2}$.

As expected, the aliphatic cyclohexanol is less reactive than 1-phenylethanol leading, under the same reaction conditions, to moderate yields (Table 4), as reported in other cases [22,23,61]. In contrast with the comparable yields obtained for cyclohexanone by $\mathrm{MW}$-assisted peroxidative oxidation of cyclohexanol with the various catalyst precursors 1-4 (entries 2, 4, 8 and 11, respectively, Table 4), the oxidation of 1 -phenylethanol, under the same conditions, appears to be more sensitive to the metal catalyst precursor. The best yields were obtained in the presence of the oxidovana$\operatorname{dium}(\mathrm{V})$ complexes 1 (94\%, entry 1, Table 4$)$ and $\mathbf{3}$ (93\%, entry 5, Table 4). They were followed by the oxidovanadium(IV) 4 (86\%,

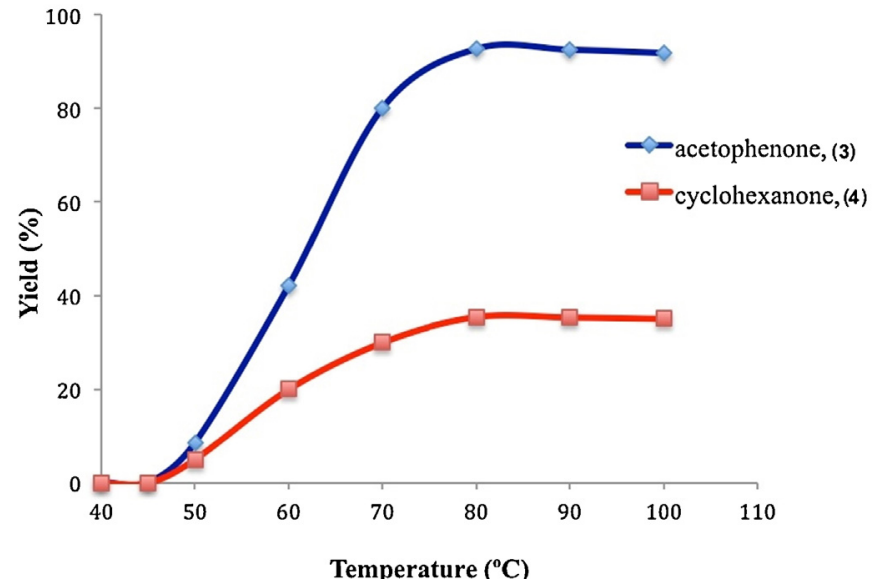

Fig. 5. Influence of the temperature on the yield of acetophenone or cyclohexanone obtained by MW-assisted oxidation of 1-phenylethanol in the presence of 3 )

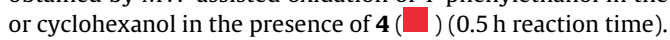

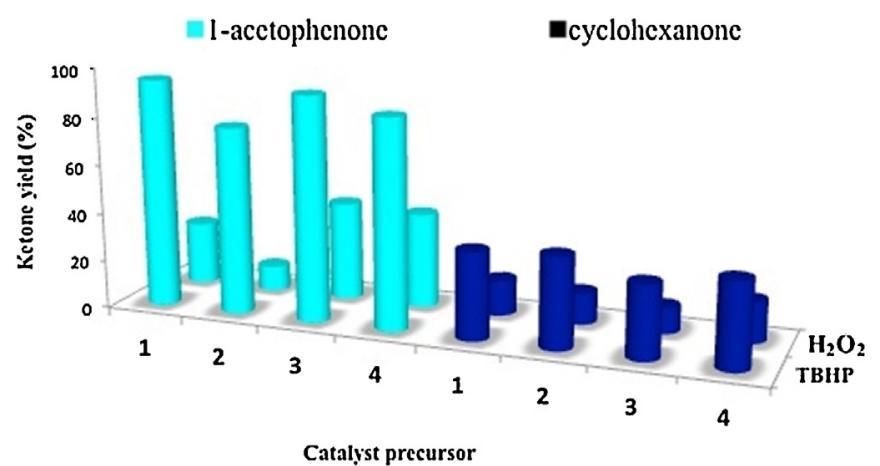

Fig. 6. Influence of the type of the oxidant on the yield of acetophenone ( ) or cyclohexanone $(\square$ ) obtained by MW-assisted oxidation of the corresponding alcohol in the presence of 1-4.

entry 11 , Table 4$)$ and then by the anionic dioxido- $V(V) 2(77 \%$, entry 3, Table 4). To achieve considerably better conversions of 2- or 3-hexanol, although still moderate, to the corresponding ketones (selectivities of $52-87 \%$ ) an extended reaction time (2.5 h) is required (see Table 5 and Fig. $4 \mathrm{~b}$ ).

Addition of TEMPO (2,2,6,6-tetramethylpiperidine-1-oxyl) radical, an efficient mediator for the aerobic oxidation of alcohols [23,24,61-65], although scarcely used for the peroxidative oxidation $[35,43,66,67]$ of those substrates, provided almost quantitative formation of acetophenone (Fig. 3) and a significant increase in cyclohexanone yield (from 38 to $58 \%$ (2), Fig. 3). It should be noted

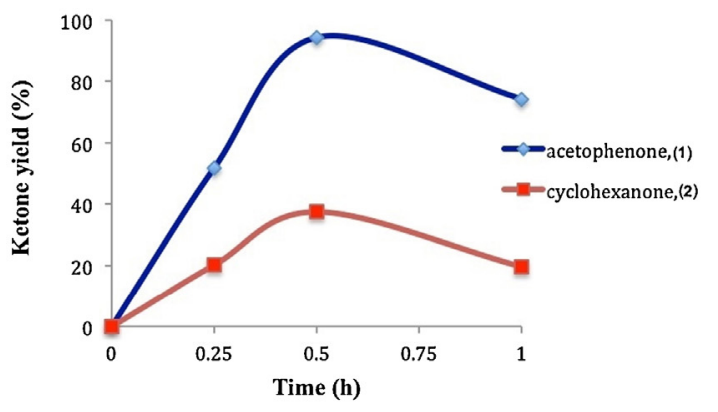

(a)

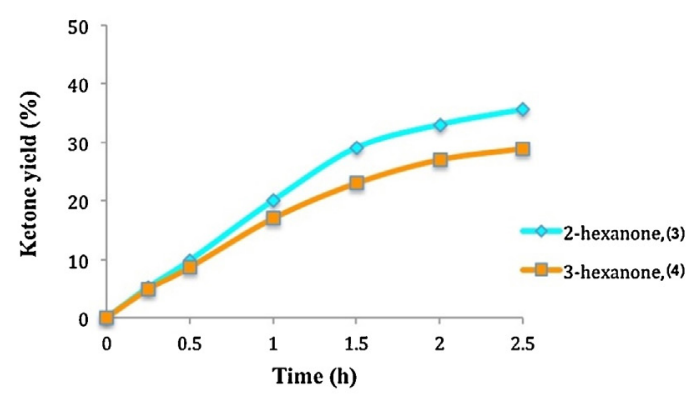

(b)

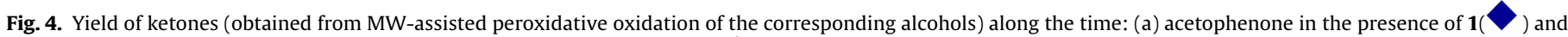
cyclohexanone in the presence of $\mathbf{2}(\square)$; (b) 2-hexanone in the presence of $\mathbf{3}$ and 3-hexanone in the presence of 4 ( $\square$ ). 
that reactions carried out with TEMPO, but in the absence of 1-4, led to very low ketone yields ( $<4 \%$, see, e.g., entries 4 and 8 , Table S2).

To our knowledge, no MW-assisted TBHP/oxidovanadium catalytic system has been previously reported and this study demonstrates its viability for the peroxidative oxidation of alcohols. A favourable effect of MW irradiation was observed, even applying the low power of $25 \mathrm{~W}$, as already reported for other systems [27]. For example, only $12 \%$ of product was obtained under the same conditions of those adopted for $\mathbf{1}$ (Table 4, entry 1 ) but using conventional heating (an oil-bath). Moreover, an increase of the acetophenone yield to $89 \%$ required $15 \mathrm{~h}$ of reaction with conventional heating, in the presence of $\mathbf{1}$.

The present catalytic system presents several advantages over those using conventional heating. For example, it allows the fast (30 min.) quantitative formation of acetophenone (Fig. 4) whereas, e.g., the $3 \mathrm{~h}$ oxidation of 1-phenylethanol with TBHP (5 M in decane) in the presence of a silica supported oxidovanadium Schiff base [41] leads to a maximum $90 \%$ yield of acetophenone [41]. However, the latter system leads to higher yields (93\%) of cyclohexanone from cyclohexanol [41]. Aerobic (by $\mathrm{O}_{2}$ ) conversions (up to 90\%) of cyclohexanol to cyclohexanone were previously obtained in the presence of $\mathrm{N}$-hydroxyphthalimide as a radical producing agent and the co-catalyst [ $\left.\mathrm{VO}(\mathrm{acac})_{2}\right]$ [38], although requiring at least $18 \mathrm{~h}$ reaction time.

A noteworthy feature of 1-4 concerns the relatively low loading ( $0.2 \mathrm{~mol} \%$ vs. substrate) necessary to reach high yields of acetophenone (i.e. up to $99 \%$ ( $\mathbf{1}$ or $\mathbf{3}$ ) in the presence of TEMPO) with substantial TOF values of 987 and $993 \mathrm{~h}^{-1}$, respectively. The effect of the amount of catalyst precursor 3 was studied for the 1-phenylethanol (entries 5-7, Table 4) and cyclohexanol (entries $8-10$, Table 4$)$ oxidations. Its increase from $1 \mu \mathrm{mol}(0.02 \mathrm{~mol} \% \mathrm{vs}$. substrate) to $10 \mu \mathrm{mol}(0.2 \mathrm{~mol} \%$ vs. substrate) results in a yield enhancement from 36 to $93 \%$ (acetophenone) or from 12 to $30 \%$ (cyclohexanone). However, beyond $10 \mu \mathrm{mol}$ of catalyst, the yield remained almost unchanged, leading to the expected TON lowering (compare e.g. entries 5 and 7 or 8 and 10, Table 4).

Blank tests (in the absence of any catalyst precursor) were performed under common reaction conditions and no significant conversion was observed $(<0.7 \%$, see, e.g., entries 1 and 5, Table $\mathrm{S} 2$ ). Moreover, the use of [ $\left.\mathrm{VO}(\mathrm{acac})_{2}\right]$ (the starting complex for the catalytic precursors) or of $\mathrm{V}_{2} \mathrm{O}_{5}$, instead of our vanadium catalysts, resulted in much lower yields (e.g., $47 \%$ or $13 \%$ for 1 -phenylethanol, and $24 \%$ or $9 \%$ for cyclohexanol, respectively, Table S2, entries 9-10, versus $94 \%$ for 1 -phenylethanol and $36 \%$ for cyclohexanol in the case of $\mathbf{1}$, Table 4 , entry 1 ).

The optimal reaction temperature is $80^{\circ} \mathrm{C}$ as depicted in Fig. 5 for the MW-assisted oxidations of 1-phenylethanol and cyclohexanol, with 3 or $\mathbf{4}$, respectively. Attempts to perform the oxidation at room temperature failed and the minimum required temperature is $\mathrm{ca}$. $45^{\circ} \mathrm{C}$. Moreover, temperatures above $80^{\circ} \mathrm{C}$ do not lead to higher ketone yields. The overall temperature coefficient of the oxidations is ca. 2.2 (temperature range of $50-80^{\circ} \mathrm{C}$ ).

Experiments with the cheaper and environmentally friendly hydrogen peroxide ( $30 \%$ aqueous solution) as oxidant are less effective, as attested by the marked yield lowering, e.g. from $94 \%$ to $26 \%$ (1) (Fig. 6), in accord with the expected decomposition of $\mathrm{H}_{2} \mathrm{O}_{2}$ under the used reaction conditions $\left(80^{\circ} \mathrm{C}\right)$. Moreover, the use of higher amounts of oxidant does not lead to a better conversion.

The previously recognized promoting effect of basic additives, which facilitate the deprotonation of the alcohol [61,62,69-75], was not detected for the present systems. In contrast, a strong inhibitor effect of the catalytic activity (Fig. 3) was observed for the reactions carried out in the presence of $1 \mathrm{M} \mathrm{K}_{2} \mathrm{CO}_{3}$ solution. Moreover, the presence of $\mathrm{HNO}_{3}$ also exhibited an inhibitory effect on the acetophenone yield (Fig. 3).
The peroxidative oxidation of the tested secondary alcohols is believed to proceed mainly via a radical mechanism which involves both carbon- and oxygen-centred radicals [76-78], in view of the strong inhibition effect observed when it is carried out in the presence of either a carbon-radical trap such as $\mathrm{CBrCl}_{3}$ (Fig. 3) or an oxygen-radical trap such as $\mathrm{Ph}_{2} \mathrm{NH}$ (Fig. 3). It may involve e.g., ${ }^{t} \mathrm{BuO} \cdot$ and ${ }^{t} \mathrm{BuOO} \cdot$ radicals produced in the $\mathrm{V}$ promoted decomposition of TBHP $[79,80]$ according to the Eqs. (1)-(6), where $\mathrm{VO}^{n+}$ represent arylhydrazone derived oxido-vanadium species. The oxidoperoxido species $[\mathrm{VO}(\mathrm{OO}) \mathrm{L}]^{-}$, conceivably involved in the catalytic process, was detected by ESI-MS (see SI).

$$
\begin{aligned}
& \mathrm{VO}^{3+}+{ }^{t} \mathrm{BuOOH} \rightarrow \mathrm{VO}^{2+}+{ }^{t} \mathrm{BuOO} \bullet+\mathrm{H}^{+} \\
& \mathrm{VO}^{2+}+{ }^{t} \mathrm{BuOOH} \rightarrow \mathrm{VO}^{3+}-\mathrm{OH}+{ }^{t} \mathrm{BuO}^{\bullet} \\
& \mathrm{VO}^{3+}-\mathrm{OH}+{ }^{t} \mathrm{BuOOH} \rightarrow \mathrm{VO}^{3+}-\mathrm{OO}-{ }^{t} \mathrm{Bu}+\mathrm{H}_{2} \mathrm{O} \\
& { }^{t} \mathrm{BuO} \bullet+\mathrm{R}_{2} \mathrm{CHOH} \rightarrow{ }^{t} \mathrm{BuOH}+\mathrm{R}_{2} \mathrm{C}^{\bullet}-\mathrm{OH} \\
& { }^{t} \mathrm{BuOO} \bullet+\mathrm{R}_{2} \mathrm{CHOH} \rightarrow{ }^{t} \mathrm{BuOOH}+\mathrm{R}_{2} \mathrm{C}^{\bullet}-\mathrm{OH} \\
& \mathrm{VO}^{3+}-\mathrm{OO}-{ }^{t} \mathrm{Bu}+\mathrm{R}_{2} \mathrm{C}^{\bullet}-\mathrm{OH} \rightarrow \mathrm{R}_{2} \mathrm{C}=\mathrm{O}+{ }^{t} \mathrm{BuOOH}+\mathrm{VO}^{2+}
\end{aligned}
$$

It may also proceed via the coordination of the alcohol substrate to an active site of the catalyst, and its deprotonation to form the alkoxide ligand, followed by a metal-centred (and TEMPO assisted) dehydrogenation $[68,71,72]$.

Other important features of the 1-4/TBHP/MW system concern the use of weak MW irradiation ( $25 \mathrm{~W}$ ) and of solvent- and additivefree oxidation conditions, which contrast with the common use of organic solvents or costly ionic liquids in many state-of-the-art methods for the oxidation of alcohols [1-4,17-19,25,26].

\section{Conclusions}

In this study, we have successfully explored the catalytic activity of four different types of vanadium complexes, i.e., an oxidoethoxidovanadium(V) (1), a salt like dioxidovanadium (2), a mixed-ligand oxidovanadium(V) (3) and a mixed-ligand oxidovanadium(IV) complex (4) towards MW-assisted homogeneous oxidation of secondary alcohols. 1-4 act as efficient and selective catalyst precursors for the mild MW-assisted oxidation of secondary alcohols (1-phenylethanol and cyclohexanol) in solventand additive-free systems. A comparative study of their catalytic efficiency has been drawn. Cyclohexanone is obtained in comparable yields in the presence of $\mathbf{1 - 4}$, while the oxidovanadium(V) complexes $\mathbf{1}$ and $\mathbf{3}$ are the most efficient ones for the peroxidative oxidation of 1-phenylethanol.

The application, for the first time, of a MW-assisted TBHP/oxidovanadium complex catalytic system for the oxidation of secondary alcohols widens the scope of peroxidative catalytic systems suitable for MW-assisted oxidative transformations of such substrates. Moreover, a cooperative action of the radical TEMPO with 1-4 towards the peroxidative oxidation of the tested alcohols was found. This study should open a new window for the catalytic application of vanadium complexes in solvent- and additive-free systems.

\section{Supporting information}

Description of the crystal structure of compound $\mathbf{4}$ is given as electronic supplementary information. CCDC 1005764 (3) and 1005765 (4) contain the supplementary crystallographic data for this paper. These data can be obtained free of charge from The Cambridge Crystallographic Data Centre via www.ccdc.cam.ac.uk/ data_request/cif. 


\section{Acknowledgments}

We are grateful for the financial support received from the Fundação para a Ciência e a Tecnologia (FCT), Portugal, and its projects PTDC/EQU-EQU/122025/2010 and PEst-OE/QUI/UI0100/ 2013. M.S. acknowledges the FCT, Portugal, for a postdoctoral fellowship (SFRH/BPD/86067/2012).

\section{Appendix A. Supplementary data}

Supplementary data associated with this article can be found, in the online version, at http://dx.doi.org/10.1016/j.apcata. 2015.01.005.

\section{References}

[1] J.-E. Bäckvall, Modern Oxidation Methods, Wiley-VCH, Weinheim, 2004, pp. 83-118.

[2] R.A. Sheldon, I. Arends, U. Hanefeld, Green Chemistry and Catalysis, Wiley-VCH, Weinheim, 2007.

[3] Ullmann's Encyclopedia of Industrial Chemistry, 6th ed., Wiley-VCH, Weinheim, 2002

[4] R.A. Smiley, H.L. Jackson, Chemistry and the Chemical Industry, CRC Press, Boca Raton, FL, 2002.

[5] G. Tojo, M. Fernández, Oxidation of Alcohols to Aldehydes and Ketones: A Guide to Current Common Practice, Springer, New York, 2006.

[6] G. Rothenberg, H. Wiener, Y. Sasson, J. Mol. Catal. A: Chem. 136 (1998) 253262.

[7] J. Singh, M. Sharma, M. Chhibber, J. Kaur, G.L. Kad, Synth. Commun. 30 (2000) 3941-3945.

[8] M. Hudlicky, Oxidations in Organic Chemistry, ACS Monograph 186, Washington, DC, 1990.

[9] I.E. Markó, P.R. Giles, M. Tsukazaki, S.M. Brown, C.J. Urch, Science 274 (1996) 2044-2046.

[10] R. Chakrabarty, P. Sarmah, B. Saha, S. Chakravorty, B.K. Das, Inorg. Chem. 48 (2009) 6371-6379.

[11] I.E. Markó, A. Gautier, R. Dumeunier, K. Doda, F. Philippart, S.M. Brown, C.J. Urch, Angew. Chem. Int. Ed. 43 (2004) 1588-1591.

[12] S.S. Stahl, Angew. Chem. Int. Ed. 43 (2004) 3400-3420.

[13] G.-J. ten Brink, I.W.C.E. Arends, R.A. Sheldon, Science 287 (2000) 1636-1639.

[14] D.S. Bailie, G.M.A. Clendenning, L. McNamee, M.J. Muldoon, Chem. Commun. 46 (2010) 7238-7240.

[15] D. Sloboda-Rozner, P.L. Alsters, R. Neumann, J. Am. Chem. Soc. 125 (2003) 5280-5281.

[16] J. Boudreau, M. Doucette, A.N. Ajjou, Tetrahedron Lett. 47 (2006) 1695-1698.

[17] O.C. Kappe, D. Dallinger, S. Murphree, Practical Microwave Synthesis for Organic Chemists, Wiley-VCH, Weinheim, Germany, 2008

[18] J.P. Tierney, P. Lidström, Microwave Assisted Organic Synthesis, Blackwell Publishing/CRC Press, Oxford, 2005.

[19] A. Loupy, Microwaves in Organic Synthesis, Wiley/VCH, Weinheim, 2002.

[20] A. De La Hoz, A. Diaz-Ortiz, A. Moreno, Chem. Soc. Rev. 34 (2005) 164-178.

[21] P.J. Figiel, A.M. Kirillov, M.F.C. Guedes da Silva, J. Lasri, A.J.L. Pombeiro, Dalton Trans. 39 (2010) 9879-9888.

[22] R.R. Fernandes, J. Lasri, M.F.C. Guedes da Silva, J.A.L. da Silva, J.J.R. Fraústo da Silva, A J. Pombeiro, Appl. Catal. A: Gen 402 (2011) 110-120.

[23] M.N. Kopylovich, A. Mizar, M.F.C. Guedes da Silva, T.C.O. MacLeod, K.T. Mahmudov, A.J.L. Pombeiro, Chem. Eur. J. 19 (2013) 588-600.

[24] M.N. Kopylovich, Y.Y. Karabach, M.F.C. Guedes da Silva, P.J. Figiel, J. Lasri, A.J.L. Pombeiro, Chem. Eur. J. 18 (2012) 899-914.

[25] V. Polshettiwar, R.S. Varma, Acc. Chem. Res. 41 (2008) 629-639.

[26] D. Betz, P. Altmann, M. Cokoja, W.A. Herrmann, F.E. Kühn, Coord. Chem. Rev. 255 (2011) 1518-1540.

[27] Y.Y. Karabach, M.N. Kopylovich, K.T. Mahmudov, A.J.L. Pombeiro, in: A.J.L. Pombeiro (Ed.), Advances in Organometallic Chemistry and Catalysis, Wiley, NJ, 2014, pp. 233-245, Chapter 18.

[28] M. Sutradhar, N.V. Shvydkiy, M.F.C. Guedes da Silva, M.V. Kirillova, Y.N. Kozlov, A.J.L. Pombeiro, G.B. Shul'pin, Dalton Trans. 42 (2013) 11791-11803.

[29] M. Sutradhar, M.V. Kirillova, M.F.C. Guedes da Silva, L.M.D.R.S. Martins, A.J.L. Pombeiro, Inorg. Chem. 5 (2012) 11229-11231.

[30] S. Gupta, M.V. Kirillova, M.F.C. Guedes da Silva, A.J.L. Pombeiro, Appl. Catal. A: Gen. 460-461 (2013) 82-89.

31] G.B. Shul'pin, Dalton Trans. 42 (2013) 12794-12818.

[32] M.V. Kirillova, M.L. Kuznetsov, V.B. Romakh, L.S. Shul'pina, J.J.R. Fraústo da Silva, A.J.L. Pombeiro, G.B. Shul'pin, J. Catal. 267 (2009) 140-157.
[33] M.V. Kirillova, M.L. Kuznetsov, P.M. Reis, J.A.L. da Silva, J.J.R. Fraústo da Silva, A.J.L. Pombeiro, J. Am. Chem. Soc. 129 (2007) 10531-10545

[34] P.M. Reis, J.A.L. Silva, A.F. Palavra, J.J.R. Fraústo da Silva, T. Kitamura, Y. Fujiwara, A.J.L. Pombeiro, Angew. Chem. Int. Ed. 42 (2003) 821-823.

[35] J.A.L. Silva, J.J.R. Fraústo da Silva, A.J.L. Pombeiro, Coord. Chem. Rev. 255 (2011) 2232-2248.

[36] J.A.L. Silva, J.J.R. Fraústo da Silva, A.J.L. Pombeiro, Coord. Chem. Rev. 257 (2013) $2388-2400$.

[37] A.T. Radosevich, C. Musich, F.D. Toste, J. Am. Chem. Soc. 127 (2005) 1090-1091.

[38] P.J. Figiel, J.M. Sobczak, J.J. Ziólkowski, Chem. Commun. 4 (2004) 244-245.

[39] B. Chen, X. Huang, B. Wang, Z. Lin, J. Hu, Y. Chi, C. Hu, Chem. Eur. J. 19 (2013) 4408-4413.

[40] A. Dewan, T. Sarma, U. Bora, D.K. Kakati, Tetrahedron Lett. 52 (2011) 2563-2565

[41] S. Verma, M. Nandi, A. Modak, S.L. Jain, A. Bhaumik, Adv. Synth. Catal. 353 (2011) 1897-1902.

[42] H.P. Mungse, S. Verma, N. Kumar, B. Sain, P. Khatri, J. Mater. Chem. 22 (2012) 5427-5433.

[43] S.-S. Wang, Z. Popovic, H.-H. Wu, Y. Liu, ChemCatChem 3 (2011) 1208-1213.

[44] M. Sutradhar, G. Mukherjee, M.G.B. Drew, S. Ghosh, Inorg. Chem. 46 (2007) 5069-5075.

[45] B. Mondal, T. Ghosh, M. Sutradhar, G. Mukherjee, M.G.B. Drew, T. Ghosh, Polyhedron 27 (2008) 2193-2201.

[46] M. Sutradhar, T. Roy Barman, S. Ghosh, M.G.B. Drew, J. Mol. Struct. 1020 (2012) $148-152$.

[47] M.R. Maurya, S. Agarwal, M. Abid, A. Azam, C. Bader, M. Ebel, D. Rehder, Dalton Trans. (2006) 937-947.

[48] M. Sutradhar, A.J.L. Pombeiro, Coord. Chem. Rev. 265 (2014) 89-124.

[49] P. Tundo, G.P. Romanelli, P.G. Vázquez, F. Aricò, Catal. Commun. 11 (2010) 1181-1184.

[50] M. Sutradhar, G. Mukherjee, M.G.B. Drew, S. Ghosh, Inorg. Chem. 45 (2006) 5150-5161.

[51] R. Dinda, P. Sengupta, M. Sutradhar, T.C.W. Mak, S. Ghosh, Inorg. Chem. 47 (2008) 5634-5640

[52] M. Sutradhar, T. Roy Barman, G. Mukherjee, M.G.B. Drew, S. Ghosh, Polyhedron 34 (2012) 92-101.

[53] Bruker, APEX2 \& SAINT, AXS Inc., Madison, WI, 2004.

[54] G.M. Sheldrick, Acta Crystallogr. A64 (2008) 112-122

[55] L.J. Farrugia, J. Appl. Crystallogr. 32 (1999) 837-838.

[56] A.L. Spek, Acta Crystallogr. A 46 (1990) C34

[57] M.R. Maurya, Coord. Chem. Rev. 237 (2003) 163-181.

[58] M. Sutradhar, T. Roy Barman, S. Ghosh, M.G.B. Drew, J. Mol. Struct. 1037 (2013) 276-282

[59] T. Ghosh, B. Mondal, T. Ghosh, M. Sutradhar, G. Mukherjee, M.G.B. Drew, Inorg Chim. Acta 360 (2007) 1753-1761.

[60] M. Sutradhar, T. Roy Barman, G. Mukherjee, M.G.B. Drew, S. Ghosh, Inorg. Chim Acta 363 (2010) 3376-3383.

[61] P.J. Figiel, A.M. Kirillov, Y.Y. Karabach, M.N. Kopylovich, A.J.L. Pombeiro, J. Mol Catal. A: Chem. 305 (2009) 178-182.

[62] K.T. Mahmudov, M.N. Kopylovich, M.F.C. Guedes da Silva, P.J. Figiel, Y.Y. Karabach, A.J.L. Pombeiro, J. Mol. Catal. A: Chem. 318 (2010) 44-50.

[63] Z. Ma, L. Wei, E.C.B.A. Alegria, L.M.D.R.S. Martins, M.F.C. Guedes da Silva, A.J.L. Pombeiro, Dalton Trans. 43 (2014) 4048-4058.

[64] J.M. Hoover, B.L. Ryland, S.S. Stahl, J. Am. Chem. Soc. 135 (2013) 2357-2367.

[65] P. Gamez, I.W.C.E. Arends, R.A. Sheldon, J. Reedijk, Adv. Synth. Catal. 346 (2004) $805-811$.

[66] M. Alexandru, M. Cazacu, A. Arvinte, S. Shova, C. Turta, B.C. Simionescu, A Dobrov, E.C.B.A. Alegria, L.M.D.R.S. Martins, A.J.L. Pombeiro, V.B. Arion, Eur. J. Inorg. Chem. (2014) 120-131.

[67] M. Sutradhar, L.M.D.R.S. Martins, M.F.C. Guedes da Silva, E.C.B.A. Alegria, C.-M Liu, A.J.L. Pombeiro, Dalton Trans. 43 (2014) 3966-3977.

[68] M.V.N. de Souza, Mini-Rev. Org. Chem. 3 (2006) 155-165.

[69] T. Vogler, A. Studer, Synthesis-Stuttgart, 2008, pp. 1979-1993.

[70] R.A. Sheldon, I.W.C.E. Arends, J. Mol. Catal. A Chem. 251 (2006) 200-214

[71] R.A. Sheldon, I.W.C.E. Arends, Adv. Synth. Catal. 346 (2004) 1051-1071.

[72] P.J. Figiel, A. Sibaouih, J.U. Ahmad, M. Nieger, M.T. Räisänen, M. Leskelä, T. Repo, Adv. Synth. Catal. 351 (2009) 2625-2632

[73] G. Yang, W. Zhu, P. Zhang, H. Xue, W. Wang, J. Tian, M. Songa, Adv. Synth. Catal. 350 (2008) 542-546

[74] L. Lin, M. Juanjuan, J. Liuyan, W. Yunyang, Catal. Commun. 9 (2008) 1379-1382.

[75] J.S. Uber, Y. Vogels, D. van den Helder, I. Mutikainen, U. Turpeinen, W.T. Fu, O. Roubeau, P. Gamez, J. Reedijk, Eur. J. Inorg. Chem. (2007) 4197-4206.

[76] L.M. Slaughter, J.P. Collman, T.A. Eberspacher, J.I. Brauman, Inorg. Chem. 43 (2004) 5198-5204.

[77] J.A. Howard, in: J.K. Kochi (Ed.), Free Radicals, vol. II, Wiley, New York, 1973, p.

[78] J.M. Mattalia, B. Vacher, A. Samat, M. Chanon, J. Am. Chem. Soc. 114 (1992) 4111-4119.

[79] L. Feldberg, Y. Sasson, Tetrahedron Lett. 37 (1996) 2063-2066.

[80] V. Mahdavi, M. Mardani, J. Chem. Sci. 124 (2012) 1107-1115. 